\title{
EFFECTS OF TETRACYCLINE INJECTION ON BLOOD CALCIUM AND RUMINAL ACTIVITY IN SHEEP
}

\author{
P. Mudron̆ \\ pavol.mudron@uvlf.sk
}

University of Veterinary Medicine and Pharmacy in Košice, clinic of ruminants, 73 Komenského, Košice 04181, Slovak Republic

Tetracycline is widely used in the treatment of the foot rot in ruminants. It chelates with $\mathrm{Ca}^{2+}$ ions causing a depression of levels of ionised calcium. The objective of the study was to assess effects of tetracycline administration on serum calcium concentrations and the frequency of ruminal contractions. Rumen contractions were monitored by auscultation in 23 sheep prior to administration of oxytetracycline and recorded every 12 hours for 84 hours after intramuscular injection of the antibiotic. Blood for calcium analyses was collected by venepuncture of the jugular vein before and 24, 48, 72, and 96 hours after administration of oxytetracycline. The serum calcium concentrations were determined by atomic absorption spectrophotometry. Analysis of variance (ANOVA) was used to analyse the time effect of tetracycline treatment on the rumen contractions and serum calcium concentrations. There was a significant decrease $(P<0.01)$ in ruminal contractions following application of oxytetracycline, with a maximum decrease at 24 hours following oxytetracycline application and a return to the initial rumen contraction frequency by 60-72 hours following oxytetracycline application. The oxytetracycline administration resulted in serum calcium decrease from $2.42 \mathrm{mmol} / \mathrm{l}$ to $2.26 \mathrm{mmol} / \mathrm{l} 24$ hours after the administration $(P<0.01)$. In conclusion, as found in our study the administration of tetracycline in sheep can be associated with a decline in ruminal motility potentially causing production losses, particularly in lactating ewes.

Keywords: CALCIUM, TETRACYCLINE, RUMEN ACTIVITY

\section{ВПЛИВ ТЕТРАЦІКЛІНУ НА КАЛЬЦІЙ КРОВІ І РУМІНАЛЬНУ АКТИВНІСТЬ В ОВЕЦЬ}

\author{
П. Мудрон
}

Університет ветеринарної медицини та фармації м. Кошице, клініка жуйних тварин, вул. Коменського, 73, м. Кошице, 04181, Словаччина

Тетрациклін широко застосовується при лікуванні гнилих стоп в жуйних тварин. Його хелатують з іонами $\mathrm{Ca}^{2+}$, пригнічуючи рівень іонізованого кальиію. Метою дослідження було оцінити вплив введення тетрацикліну на сироваткові концентрації кальцію та частоту скорочень рубия. Контракиію рубия контролювали аускультативно у 23 овещь перед введеннял окситетрачикліну та реєстрували кожсні 12 годин протягом 84 годин після внутрішньом'язового введення антибіотика. Кров для аналізу кальиію збирали венепункиією яремної вени до і через 24, 48, 72 та 96 год після введення окситетраиикліну. Конщентрачії кальиію в сироватиі крові визначали атомно-абсорбиійною спектрофотометрією. Аналіз дисперсї (ANOVA) був використаний для аналізу часового впливу терапії тетрачикліном на скорочення рубия та концентрациї кальцію в сироватиі крові. Відбулося суттєве зменшення $(P<0,01)$ скорочень рубия після застосування окситетрацикліну з максимальним зменшенням через 24 год після застосування окситетраиикліну та повернення до початкової частоти скорочення рубия на 60-72 год після застосування окситетрацикліну. Введення окситетрацикліну призвело до зниження кальиію в сироватиі крові з 2,42 ммоль/л до 2,26 ммоль/л через 24 год після введення (P<0,01). Загалом, як виявлено в намому дослідженні, введення тетраиикліну в овець може викликати зниження активності рубия, щуо потенційно може призвести до втрат у виробництві, особливо в овець під час лактаиії.

\section{Ключові слова: КАЛЬЦІЙ, ТЕТРАЦИКЛІН, АКТИВНІСТЬ РУБЦЯ}

The group of tetracyclines belongs to broad-spectrum antibiotics and is composed of: tetracycline, oxytetracycline, doxycycline and minocycline. They are actively transported into prokaryotic cells and inhibit protein synthesis by competing with tRNA for the A site of 
the ribosome. They have a bacteriostatic effect. Tetracyclines chelate metal ions such as calcium, magnesium, iron and aluminum, forming nonabsorbable complexes. Therefore if given orally, the presence of milk, antacids or iron preparations can decrease absorption. Undesirable effects of the drug include gastrointestinal disturbances due to direct irritation and modification of the normal gut flora, and vitamin B complex deficiency can occur as a consequence. Since they chelate with $\mathrm{Ca}^{2+}$ ions, tetracyclines are deposited in bones and teeth, causing staining and sometimes dental hypoplasia and bone deformities [7]. Rumen and abomasal motilities are reduced in hypocalcaemia due to the general effects of a depression of levels of ionised calcium on smooth muscle contractility and on neuromuscular transmission [5].

Tetracycline is widely used in the treatment of the foot rot in ruminants. In a study of 209 sheep farmers, those which treated sheep with foot rot using parenteral antibiotics and foot sprays had a peak prevalence of $2 \%$, as opposed to a peak prevalence of $9 \%$ in farmers who treated foot rot by hoof trimming and topical spraying [12]. In other study, treatment of foot rot with parenteral oxytetracycline reduced clinical lameness in sheep significantly [8].

The aim of the study was to assess effects of long acting tetracycline administration on the number of ruminal contractions and serum calcium concentrations.

\section{Materials and methods}

Rumen contractions were monitored in 23 adult merino female sheep (mean body weight was $49 \mathrm{~kg}$ ) prior to administration of oxytetracycline and recorded every 12 hours for 84 hours after intramuscular injection of the antibiotic. The sheep were admitted to the clinic for treatment of the foot rot. After the diagnosis of foot rot, patients were treated with a single intramuscular injection of a long acting oxytetracycline (Tetradur LA 300, $30 \mathrm{mg} / \mathrm{kg}$ ). The drug was administered into the neck muscles $(5 \mathrm{ml})$. Feeding of the experimental animals consisted of $0.2 \mathrm{~kg}$ of concentrates, and free access to hay and water. Rumen contractions were counted by placing a stethoscope in the para-lumbar fossa on the left side of the animal and counting the number of ruminal contractions over a 5-minute period. In addition, intensity of the rumen contractions was assessed by auscultation in the same time. Blood was collected by venepuncture of the jugular vein before and 24, 48, 72, and 96 hours after administration of oxytetracycline. The serum calcium concentrations were determined by flame AAS method (Perkin Elmer AAnalyst 100). Analysis of variance (ANOVA) with the post hoc Bonferroni test (IBM SPSS Statistics 23,2015 ) was used to analyse the time effect of tetracycline treatment on the rumen contractions and serum calcium concentrations.

\section{Results and discussion}

ANOVA revealed a significant decrease $(\mathrm{P}<0.01)$ in ruminal contractions following application of oxytetracycline, with a maximum decrease at 24 hours following oxytetracycline application and a return to the initial rumen contraction frequency by 60-72 hours following oxytetracycline application (table). As well as a reduction in the frequency of ruminal contractions, there was a decrease in the intensity of the contractions. In general, the contractions became quieter and sometimes difficult to distinguish effectively. Typically around 24 hours after antibiotic administration the intensity was at its lowest, coinciding with the greatest decrease in frequency. The strength of contractions gradually returned to normal over the same time period as contraction frequency.

The rumen contractions and serum calcium after oxytetracycline administration $(x \pm s)$

\begin{tabular}{|l|c|c|}
\hline $\begin{array}{c}\text { Collection time, } \\
\text { hours }\end{array}$ & $\begin{array}{c}\text { Rumen contractions, } \\
\text { n/5 min }\end{array}$ & $\begin{array}{c}\text { Serum calcium, } \\
\mathrm{mmol} / 1\end{array}$ \\
\hline 0 & $7.31 \pm 1.55$ & $2.42 \pm 0.11$ \\
\hline 12 & $5.17 \pm 1.32^{*}$ & \\
\hline 24 & $4.09 \pm 1.16^{*}$ & $2.26 \pm 0.04^{*}$ \\
\hline 36 & $5.00 \pm 1.21^{*}$ & \\
\hline 48 & $5.96 \pm 1.19^{*}$ & \\
\hline 60 & $7.17 \pm 1.34$ & \\
\hline 72 & $7.65 \pm 1.37$ & $2.28 \pm 0.09^{*}$ \\
\hline 84 & $7.57 \pm 1.34$ & \\
\hline 96 & & $2.41 \pm 0.05$ \\
\hline ANOVA & $\mathrm{P}<0.01$ & $\mathrm{P}<0.01$ \\
\hline
\end{tabular}

Note: * - values differ to 0 at $\mathrm{P}<0.05$ (Bonferroni test). 
The oxytetracycline administration resulted in serum calcium decrease from $2.42 \mathrm{mmol} / \mathrm{l}$ to $2.26 \mathrm{mmol} / 124$ hours after the administration (table). The serum calcium concentrations continued to decrease reaching the lowest values 48 hours after the drug injection $(2.23 \mathrm{mmol} / \mathrm{l})$. ANOVA showed a strong significant effect of the oxytetracycline administration on serum calcium $(\mathrm{P}<0.01)$.

Rumen motility has a direct effect on the productivity levels of livestock, particularly on milk production. The number of ruminal contractions is dependent upon the type of feed (forage, concentrate), feed quality (herbage, rice straw), the form in which feed is ingested (hay, pellets), the amount of feed consumed and rumen wall stimulation [3]. Ruminal contraction frequency is highest during feeding (2.7 frequency/min). Second highest frequency is recorded during rumination (2.3 frequency/min), while the lowest frequency is recorded during rest periods (2.0 frequency/min) [11]. In the present experiment in 23 sheep, the frequency of ruminal contractions decreased by $44 \%$, with the lowest number of contractions recorded 24 hours after application of long acting oxytetracycline. However, our study did not take into account other factors affecting rumen contractions, such as feeding regimen, composition of the dietary ration, underlying disease processes and environmental temperature [9].

Rumen and abomasal motilities are reduced in hypocalcaemia due to the general effects of a depression of levels of ionised calcium on smooth muscle contractility and on neuromuscular transmission [4]. In general, the tetracyclines can be divided into three groups based on their pharmacokinetic and antibacterial properties. The mostly used drugs are from the group 1: this group consists of the older agents which have reduced absorption and are less lipophilic than newer drugs and include tetracycline, oxytetracycline, chlortetracycline, demeclocycline (demethyl chlorotetracycline), lymecycline, methacycline, and rolitetracycline. All these tetracyclines form insoluble complexes with calcium, magnesium, iron and aluminium, which can markedly reduce their absorption [1]. According to the pharmacodynamic study, intramuscular administration of oxytetracy- cline resulted in plateau-shaped concentration-time curves in serum and synovial fluid. Peak levels in serum $(1.68 \pm 0.47 \mu \mathrm{g} / \mathrm{ml})$ occurred at $3-8$ hours post injection [2]. As oxytetracycline chelates $\mathrm{Ca}^{2+}$ ions, once the antibiotic reaches the bloodstream it will chelate with calcium in the serum, resulting in hypocalcaemia. One mole of oxytetracycline may form complexes with 1-2 moles of calcium, depending on the relative concentrations [6].

The calcium homeostatic mechanism operates very tightly to maintain extracellular calcium within physiological ranges. A change in physiological status, such as the initiation of lactation, creates a rapid disturbance in this mechanism. Plasma calcium exchanges with a large mass of calcium in soft tissues and bone surfaces, which may function to buffer the effect of such rapid changes in these pools. The sufficient calcium levels are necessary to decrease the incidence of periparturient hypocalcaemia (milk fever) in sheep [10]. The results presented in this study did reveal a significant serum calcium-lowering effect when each of the 23 animals was given oxytetracycline. The drop in blood calcium was not associated with any clinical sign, like neurological or locomotor disturbances. However, the most of the experimental animals demonstrated a decrease in ruminal contractions.

\section{Conclusion}

In conclusion, the administration of tetracycline in sheep can be associated with a decline in ruminal motility potentially causing the decline in ruminal motility can cause production losses, particularly in lactating ewes. Despite the resulting transient production decreases, oxytetracycline remains the antibiotic drug of choice for the treatment of bacterial infections in small ruminants, foot rot especially.

Perspectives of future investigations. Further work to investigate effects of other antimicrobial drugs on foot rot and digestive processes will provide more insight into bacterial disease management in sheep. In particular, the comparison of vaccination strategies with systemic antibiotic treatment of foot rot in small ruminants can add a growing body of evidence supporting production efficacy in sheep herds. 
1. Agwuh K. N., MacGowan A. Pharmacokinetics and pharmacodynamics of the tetracyclines including glycylcyclines. Journal of Antimicrobial Chemotherapy, 2006, vol. 58, issue 2, pp. 256265. DOI: $10.1093 / \mathrm{jac} / \mathrm{dkl} 224$.

2. Bengtsson B., Franklin A., Luthman J., Jacobsson S.-O. Concentrations of sulphadimidine, oxytetracycline and penicillin $\mathrm{G}$ in serum, synovial fluid and tissue cage fluid after parenteral administration to calves. Journal of Veterinary Pharmacology and Therapeutics, 1989, vol. 12, issue 1, pp. 37-45. DOI: 10.1111/j.13652885.1989.tb00639.x.

3. Colvin H. W., Digesti R. D., Louvier J. A. Effect of succulent and nonsucculent diets on rumen motility and pressure before, during and after eating. Journal of Dairy Science, 1978, vol. 61, issue 10, pp. 1414-1421. DOI: 10.3168/jds.S00220302(78)83743-6.

4. Ebashi S. Calcium ion and muscle contraction. Nature, 1972, vol. 240, pp. 217-218. DOI: 10.1038/ $240217 \mathrm{a} 0$.

5. Hara S., Ikegaya Y., Jørgensen R. J., Sasaki J., Nakamura M., Tomizawa N. Effect of induced subclinical hypocalcemia on the motility of the bovine digestive tract. Acta Veterinaria Scandinavica, 2003, vol. 44, suppl. 1, article no. P76. DOI: 10.1186/1751-0147-44-S1-P76.

6. Ibsen K. H., Urist M. R. Complexes of calcium and magnesium with oxytetracycline. Proceed- ings of the Society for Experimental Biology and Medicine, 1962, vol. 109, issue 4, pp. 797-801. DOI: 10.3181/00379727-109-27339.

7. Neuvonen P. J. Interactions with the absorption of tetracyclines. Drugs, 1976, vol. 11, issue 1, pp. 4554. DOI: 10.2165/00003495-197611010-00004.

8. Strobel H., Lauseker M., Forbes A. B. Targeted antibiotic treatment of lame sheep with footrot using either oxytetracycline or gamithromycin. VetRecord, 2014, vol. 174, issue 2, p. 46. DOI: $10.1136 / v r .101840$.

9. Sunagawa K., Arikawa Y., Higashi M., Matsuda H., Takahashi H., Kuriwaki Z., Kojiya Z., Uechi S., Hongo F. Direct effect of a hot environment on ruminal motility in sheep. Asian-Australasian Journal of Animal Sciences, 2002, vol. 15, issue 6, pp. 859-865. DOI: 10.5713/ajas.2002.859.

10. Takagi H., Block E. Effects of reducing on calcium kinetics dietary cation-anion balance in sheep. Jomnal of Dairy Science, 1991, vol. 74, issue 12, pp. 4225-4237. DOI: 10.3168/jds. S0022-0302(91)78618-9.

11. Tsuda T. Digestion and absorption. In: Animal Physiology. Ed. by T. Tsuda. Youkendo, Tokyo, 1994, pp. 161-162.

12. Wassink G. J., Grogono-Thomas R., Moore L. J., Green L. E. Risk factors associated with the prevalence of footrot in sheep from 1999 to 2000 . VetRecord, 2003, vol. 152, issue 12, pp. 351-358. DOI: $10.1136 /$ vr.152.12.351. 